\title{
Efek Simultanitas Variabel Moneter Terhadap Neraca Pembayaran Di Lima Negara
}

\author{
Dewi Mahrani Rangkuty ${ }^{1}$, Ade Novalina ${ }^{2}$, Alan Muhammad Fauzi ${ }^{3}$ \\ 1) 2) 3) Program Studi Ekonomi Pembangunan, Fakultas Sosial Sains, \\ Universitas Pembangunan Panca Budi, email : ${ }^{1)}$ dewimahrani@dosen.pancabudi.ac.id
}

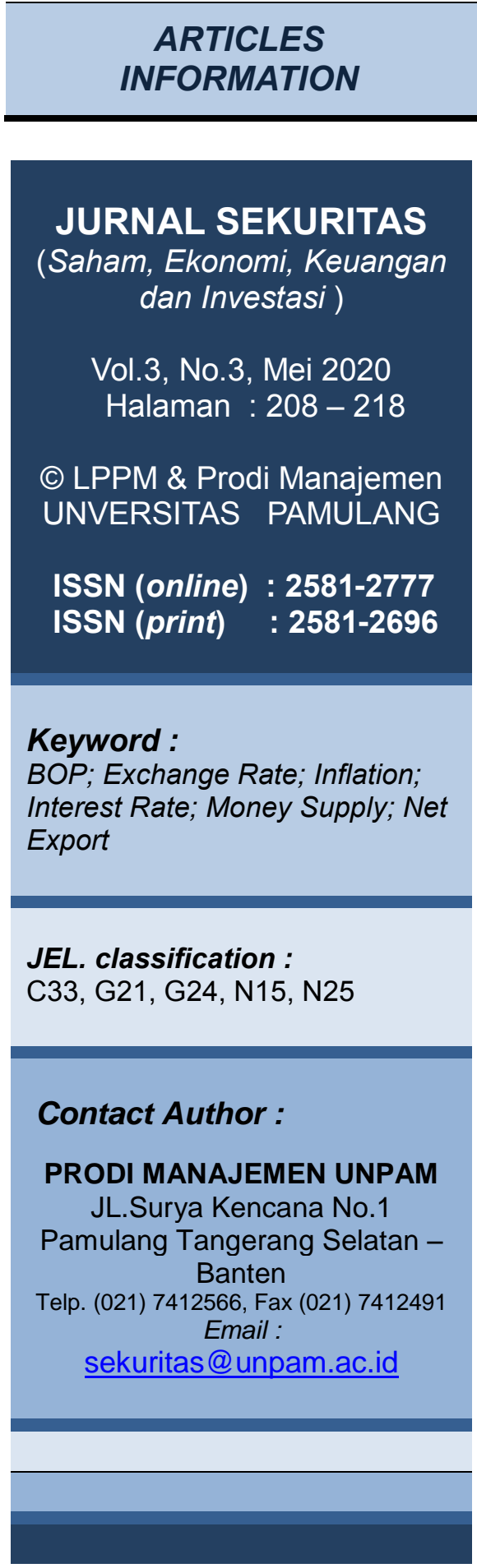

\section{ABSTRACT}

Yang menjadi tujuan penelitian ini adalah untuk menganalisis efek simultanitas variabel ekonomi moneter terhadap neraca pembayaran di lima negara yakni Indonesia, Korea Selatan, India, Brasil dan Meksiko. Dengan menggunakan data time series dari tahun 2000 sampai dengan 2018 dan cross section lima negara maka metode penelitian yang digunakan adalah pendekatan simultan Panel-Two Stage Least Square yang sebelumnya sudah berdasarkan hasil uji identifikasi. Hasil penelitian menunjukkan bahwa simultanitas terjadi antar variabel kurs mata uang di lima negara terhadap neraca pembayaran di lima negara tersebut pula dan begitu juga sebaliknya pada $\alpha=10 \%$. Kurs mata uang berpengaruh negatif dan signifikan terhadap neraca pembayaran di negara Indonesia, Korea Selatan, India, Brasil dan Meksiko, begitu pula sebaliknya.

The purpose of this research is to analyze the effect of the simultaneity of the monetary economic variables on the balance of payments in five countries, namely Indonesia, South Korea, India, Brazil, and Mexico. Using the data time series from 2000 to 2018 and the five-country cross-section, the research method used is the Panel's simultaneous approach-Two Stage Least Square which was previously based on the results of the identification test. The results showed that simultaneity occurred between currency variables in five countries against the balance of payments in the five countries also and vice versa at $\alpha=$ $10 \%$. Currency exchange rates negatively and significantly affect the balance of payments in the countries of Indonesia, South Korea, India, Brazil, and Mexico, as well as vice versa. 


\section{A. PENDAHULUAN}

Pada zaman era digital masa sekarang ini mencerminkan semakin terbukanya akses informasi terhadap sistem perekonomian global yang menuntut daya saing untuk memperoleh keuntungan ekonomi suatu negara. Perekonomian global yang memberi keuntungan suatu negara dapat dilihat dari neraca pembayaran (Astuti, IP; Oktavilia, 2015). Keuntungan di neraca pembayaran suatu negara dari transaksi perdagangan internasional perekonomian terbuka disebut juga sebagai surplus neraca pembayaran. Kondisi surplus inilah yang mencerminkan keberhasilan suatu negara dalam memaksimalkan kegiatan transaksi internasional di pasar global.

Stabilitas perekonomian suatu negara menjadi sangat penting dalam mempertahankan angka laju pertumbuhan baik untuk negara maju maupun negara berkembang. Melalui kegiatan perdagangan internasional barang dan jasa yang merupakan salah satu komponen dari pertumbuhan ekonomi menjadi sangat penting untuk dilakukan setiap negara yang menganut sistem perekonomian terbuka. Semua kegiatan dicatat di dalam laporan yang disebut neraca pembayaran (Leonufna, L; Kumaat, R; Mandeij, 2016).

Neraca pembayaran merupakan catatan dari seluuh transaksi ekonomi antara penduduk suatu negara dengan penduduk negara lain pada suatu periode tertentu dimana transaksi tersebut terdiri dari transaksi berjalan, transaksi modal dan transaksi finansial (BI, 2020). Segala interaksi kegiatan internasional dicatat di dalam neraca pembayaran sehingga menjadi laporan keuntungan perekonomian suatu negara dalam perdagangan internasional. Sumber keuntungan yang diperoleh melalui besaran cadangan devisa, kredit dalam negeri, termasuk pada investasi yang mengakibatkan aliran masuk modal dan aliran keluar modal.

Salah satu komponen di dalam neraca permbayaran yakni neraca perdagangan yang di dalamnya merupakan ikhtisar kegiatan transaksi ekspor dan impor suatu negara atau disebut juga net ekspor, yakni perhitungan ekspor dikurangi impor. Ekspor impor barang ataupun jasa memiliki korelasi yang kuat terhadap neraca perdagangan (Wiryanti, 2015). Dan surplus neraca perdagangan berarti angka ekspor lebih besar daripada impor. Inilah yang memberi dampak terhadap saldo neraca pembayaran suatu negara.

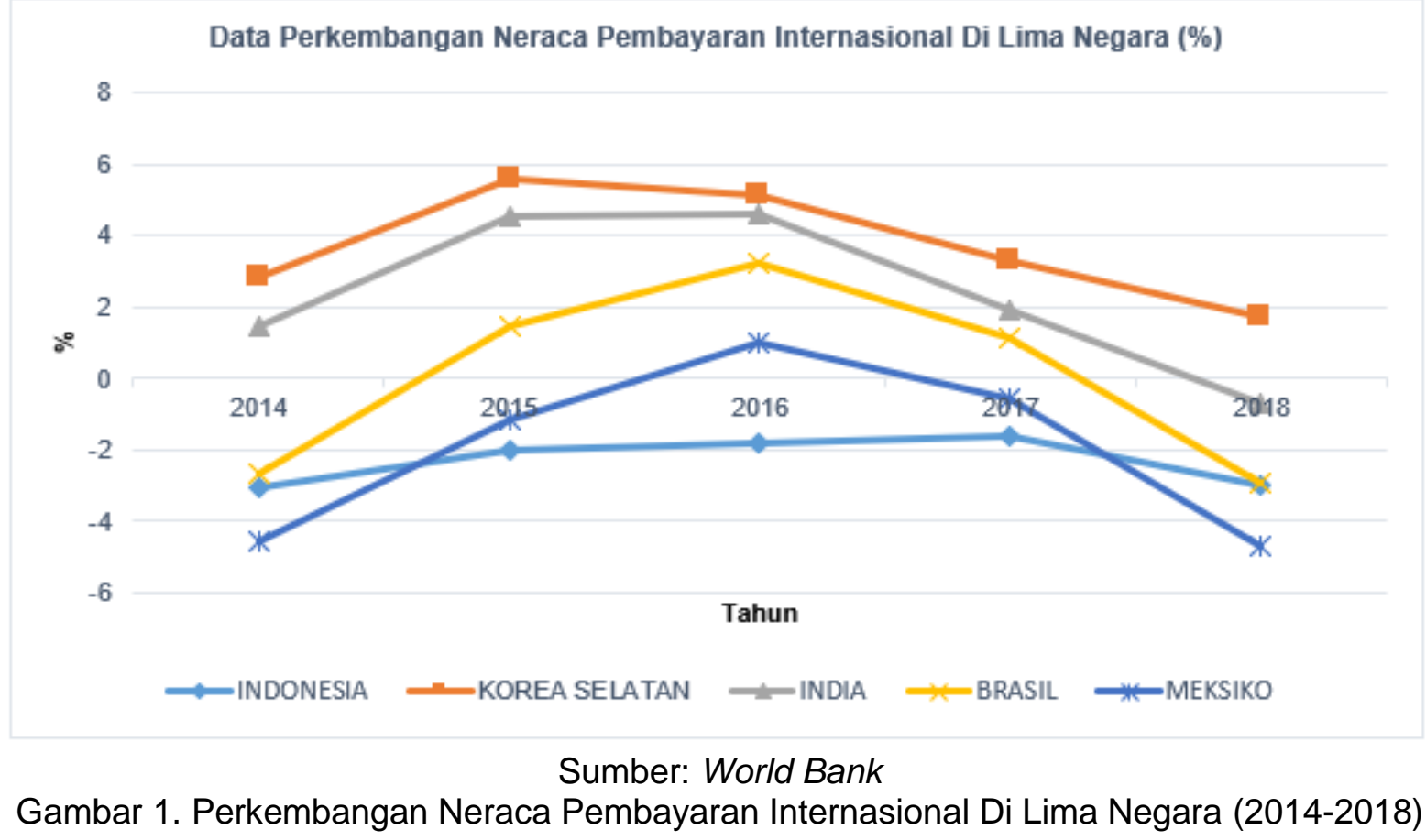


Berdasarkan Gambar di atas, data fluktuasi pertumbuhan neraca pembayaran Indonesia, Korea Selatan, India, Brasil dan Meksiko di tahun 2014, 2015, dan 2016 negara-negara seperti Indonesia, Korea Selatan, India, Brasil dan Meksiko mengalami fluktuasi neraca pembayaran (balance of payment). Indonesia di tahun 2014 adalah sebesar $-3,08 \%$ dan tahun 2015 sebesar $-2,04 \%$, satu tahun berselang tepatnya di tahun 2016 sebesar $-1,82 \%$. Korea Selatan di tahun 2014 sebesar $5,88 \%$ dan tahun 2015 sebesar $7,60 \%$ dan satu tahun berselang tepatnya di tahun 2016 sebesar 6,92\%. India di tahun 2014 sebesar $-1,34 \%$ dan tahun 2015 sebesar $-1,07 \%$, satu tahun berselang tepatnya di tahun 2016 sebesar $-0,53 \%$. Negara Brasil di tahun 2014 sebesar $-4,13 \%$ dan tahun 2015 seebsar $-3,02 \%$ dan satu tahun berselang tepatnya di tahun 2016 sebesar $-1,35 \%$. Meksiko di tahun 2014 sebesar $-1,90 \%$ dan tahun 2015 sebesar $-2,64 \%$ dan satu tahun berselang tepatnya di tahun 2016 sebesar $2,25 \%$. Rata-rata trend menurun pada setiap negara dikarenakan kecenderungan impor daripada ekspor sehingga menunjukkan angka pertumbuhan yang negatif.

Terjadinya defisit neraca pembayaran (balance of payment) di masing-masing negara mulai dari Indonesia, India, Brasil dan Meksiko pada tahun 2018, dimana untuk Indonesia sebesar $-2,98 \%$ dari $-1,60 \%$ di tahun sebelumnya. India sebesar $-2,41 \%$ dari $-1,44 \%$ di tahun sebelumnya. Brasil mengalami hal yang sama yaitu sebesar $-2,22 \%$ dari $-0,73 \%$ di tahun sebelumnya. Meksiko sebesar $-1,80 \%$ dari $-1,74 \%$ di tahun sebelumnya. Melemahnya angka laju pertumbuhan neraca pembayaran negara-negara di atas merupakan dampak dari perang dagang Amerika dan China di perekonomian global dan hal ini berdampak juga pada pertumbuhan ekonomi global yang terhambat sehingga mengakibatkan lesunya perdagangan internasional.

Aktivitas perdagangan internasional minimal melibatkan antar dua negara dan bahkan lebih. Oleh sebab itu dibutuhkan alat pembayaran yang merupakan konversi mata uang antar negara dalam perdagangan internasional, disebut dengan kurs (foreign exchange rate). Kurs adalah perbandingan nilai atau harga dari mata uang tersebut (Muchlas, Z; Alamsyah, 2015). Oleh sebab itu, kurs merupakan salah satu harga yang penting dalam suatu perekonomian terbuka pasar global perdagangan internasional.

Kurs atau nilai tukar memiliki pengaruh terhadap saldo neraca pembayaran melalui pendekatan Keynesian. Perubahan nilai tukar dapat dijelaskan melalui mekanisme harga. Jika mata uang suatu negara terdepresiasi, maka dapat menyebabkan terjadinya defisit neraca pembayaran dan begitu pula sebaliknya jika mata uang suatu negara terapresiasi, maka dapat menyebabkan terjadinya surplus neraca pembayaran (Julian, 2016).

Data Perkembangan Kurs Mata Uang Lima Negara terhadap US\$ (LCU)

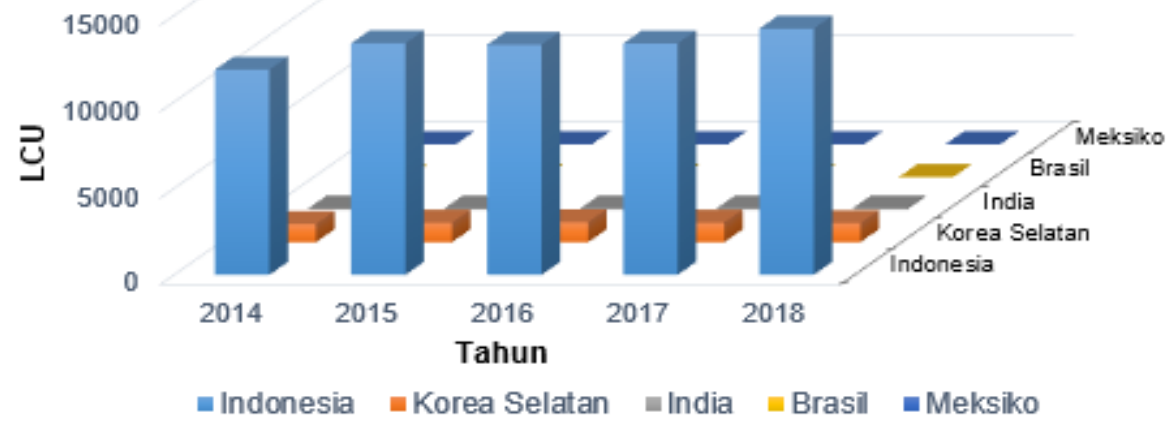

Sumber: World Bank

Gambar 2. Perkembangan Kurs Mata Uang Lima Negara terhadap US\$ (2014-2018) 
Berdasarkan Gambar di atas negara Indonesia, Korea Selatan, India, Brasil dan Meksiko mengalami depresiasi kurs di tahun 2015, kurs Indonesia di angka 13289/USD dari 11865/USD di tahun sebelumnya. Korea Selatan mengalami depresiasi kurs di angka 1131/USD dari 1052/USD di tahun sebelumnya. India depresiasi kurs di angka 64.15/USD dari 61.03/USD di tahun sebelumnya. Brasil depresiasi kurs di angka 3.327/USD dari 2.353/USD di tahun sebelumnya. Negara terakhir yakni Meksiko juga mengalami depresiasi kurs di tahun 2015 yakni di angka 15.848/USD yang di tahun sebelumnya 13.292/USD. Hal ini merupakan dampak dari dari krisis ekonomi yang terjadi di negara-negara Eropa juga Amerika. Hal ini mengakibatkan daya beli masyarakat di setiap negara pada umumnya menurun karena mata uang setiap negara terdepresiasi.

Tahun 2017 di negara-negara seperti Indonesia, Korea Selatan dan Meksiko mengalami depresiasi kurs. Indonesia di tahun 2017 mengalami depresiasi kurs di angka 13380/USD dari 13308/USD di tahun sebelumya. Negara Korea Selatan mengalami hal yang sama yakni depresiasi kurs di tahun 2017 di angka 1130/USD dari 1160 di tahun sebelumnya. Negara Meksiko juga mengalami depresiasi kurs di tahun 2017 di angka 18.927/USD dari 18.664/USD di tahun sebelumnya. Hal ini dikarenakan kenaikan suku bunga yang dilakukan oleh bank sentral AS.

Tahun 2018 di negara-negara seperti Indonesia, India, Brasil dan Meksiko mengalami depresiasi kurs yang bersamaan. Indonesia di tahun 2018 berhenti di angka 14236/USD dari 13380/USD di tahun sebelumnya. Negara India mengalami depresiasi kurs di angka 68.389/USD dari 65.122/USD di tahun sebelumnya. Negara Brasil mengalami depresiasi kurs di angka 3.654/USD dari 3.191/USD di tahun sebelumnya. Negara Meksiko mengalami depresiasi kurs di angka 19.244/USD dari 18.927/USD di tahun sebelumnya. Hal ini dikarenakan adanya perang dagang di pasar global.

Sebagai alat tukar bayar dalam aktivitas perdagangan internasional, kestabilan kurs sangat mempengaruhi saldo neraca pembayaran suatu negara pada setiap periode. Kurs juga dipengaruhi oleh variabel ekonomi makro lainnya menuju kestabilan alat tukar di setiap negara. Salah satunya jumlah uang beredar. Jumlah uang beredar adalah jumlah uang yang beredar di tangan masyarakat yang jatuh ke pasar untuk transaksi ekonomi barang atau jasa. Jumlah uang beredar berpengaruh signifikan terhadap kurs (Oktavia, 2016). Semakin banyak jumlah uang beredar mempengaruhi kestabilan kurs suatu negara.

Inflasi adalah salah satu variabel ekonomi moneter yang juga dapat mempengaruhi kestabilan kurs. Inflasi merupakan kenaikan harga barang-barang dan jasa secara keseluruhan dan terjadi secara terus menerus dalam periode waktu tertentu. Inflasi berpengaruh signifikan terhadap kurs (Dewi, 2018). Sehingga apabila terjadi inflasi yang melonjak tinggi akan berdampak buruk terhadap perekonomian suatu negara. Inflasi tinggi akan menyebabkan kecenderungan impor yang nantinya angka ekspor lebih kecil daripada impor. Ini nantinya berdampak pada defisit neraca pembayaran suatu negara.

Suku bunga adalah sejumlah uang yang harus dibayar sebagai balas jasa pinjaman per unit waktu. Apabila suku bunga dalam negeri naik maka akan menyebabkan kurs terapresiasi sebab mata uang dalam negeri menguat namun apabila suku bunga luar negeri naik maka akan menyebabkan kurs terdepresiasi. Dan tingkat suku bunga dalam negeri yang turun mengakibatkan kurs terdepresiasi, nilai mata uang dalam negeri melemah (Oktavia, 2016). Dari variabel moneter yang telah dijelaskan di atas, maka adapun tujuan daripada penelitian ini adalah untuk menganalisis efek simultanitas variabel ekonomi moneter terhadap neraca pembayaran internasional di lima negara yakni mulai dari Indonesia, Korea Selatan, India, Brasil dan Meksiko. 


\section{B. METODOLOGI PENELITIAN}

Dengan menggunakan data time series yang bersumber dari World Bank dari tahun 2000-2018, penelitian ini menggunakan metode Two Stage Least Square (TSLS) persamaan simultan dengan software EViews v.10. Dalam banyak situasi ekonomi, hubungan variabel ekonomi tidak hanya bersifat satu arah namun bersifat saling mempengaruhi. Terjadinya hubungan antar variabel bersifat dua arah disebut model persamaan simultan dengan metode TSLS (Widarjono, 2014). Model analisis yang digunakan untuk lima negara (Indonesia, Korea Selatan, India, Brasil dan Meksiko) adalah seperti berikut:

$$
\begin{aligned}
& N I_{t}=Y_{10}+Y_{11} N X+Y_{12} I N F+Y_{13} K U R S+e_{1} \\
& K U R S_{t}=Y_{20}+Y_{21} J U B+Y_{22} S B+Y_{23} N P I+e_{2}
\end{aligned}
$$

dimana:

$\begin{array}{ll}\mathrm{V}_{10}, \mathrm{Y}_{20} & =\text { intersep/konstanta } \\ \text { NPI } & =\text { neraca pembayaran internasional }(\%) \\ \text { NX } & =\text { net ekspor (milyar US\$) } \\ \text { KURS } & =\text { kurs atau nilai tukar (LCU) } \\ \text { JUB } & =\text { jumlah uang beredar }(\%) \\ \text { SB } & =\text { suku bunga (\%) } \\ \mathrm{V}_{11} \mathrm{Y}_{12} \mathrm{Y}_{13} \mathrm{Y}_{21} \mathrm{~V}_{22} \mathrm{~V}_{23} & =\text { koefisien/parameter } \\ \mathrm{t} & =\text { waktu }(\text { time) } \\ \mathrm{e}_{1}, \mathrm{e}_{2} & =\text { error term }\end{array}$

Sebelum estimasi menggunakan metode TSLS, perlu dilakukan uji identifikasi (Ajija, Shochrul Rohmatul, 2011). Berikut merupakan tahapan uji identifikasi sebelum menuju TSLS yang hasilnya dapat dilihat pada Tabel berikut:

Tabel 1. Hasil Uji Identifikasi

\begin{tabular}{llccc}
\hline Persamaan & K-k & $\mathbf{m}-1$ & Keterangan & Kesimpulan \\
\hline NPI & $6-3$ & $2-1$ & $3<1$ & Over identifield \\
\hline KURS & $6-3$ & $2-1$ & $3<1$ & Over identifield \\
\hline
\end{tabular}

Dari hasil uji identifikasi diperoleh bahwa kedua persamaan adalah over identified atau terlalu teridentifikasi. Ketika persamaan simultan adalah terlalu teridentifikasi maka digunakan metode TSLS (Widarjono, 2014). Dengan demikian tahapan estimasi dapat dilanjutkan dengan metode dua tahap TSLS.

\section{HASIL DAN PEMBAHASAN}

Jumlah uang beredar merupakan salah satu variabel ekonomi moneter yang mempengaruhi pergerakan dan kestabilan nilai mata uang suatu negara. Jumlah uang beredar dan kurs menunjukkan pengaruh yang signifikan (Syah, 2017). Dalam perekonomian global, kurs sebagai alat tukar pembayaran dipengaruhi oleh variabel yang salah satunya yakni jumlah uang beredar tersebut. Di pasar global kita mengenalnya dengan istilah valuta asing. Nilai mata uang negara lain yang dianggap sebagai alat tukar perbandingan terhadap nilai mata uang negara yang melakukan transaksi ekspor dan impor. Valuta asing mempengaruhi kestabilan kurs dalam perdagangan internasional. Jumlah uang beredar di suatu negara berlebih ini mempengaruhi nilai mata uang negara yang bersangkutan sehingga terjadi depresiasi sebab tidak diimbangi dengan permintaan yang sesuai. Sebaliknya, permintaan terhadap uang meningkat dibandingkan dengan penawaran maka kurs mata uang akan mengalami apresiasi (Salvatore, 2014). 


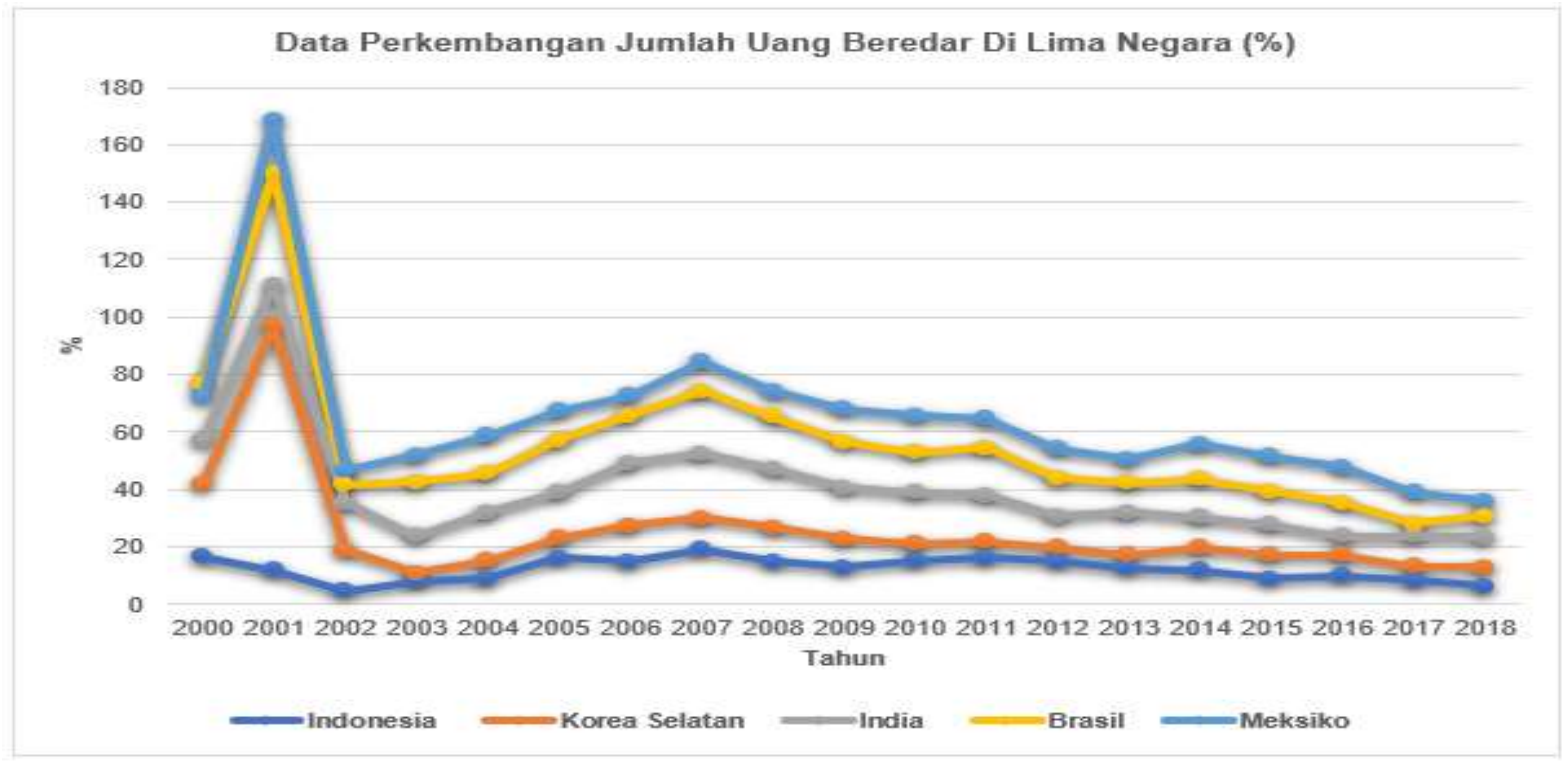

Sumber: World Bank

Gambar 3. Perkembangan Jumlah Uang Beredar Di Lima Negara (2000-2018)

Pada Gambar di atas merupakan pergerakan jumlah uang beredar di lima negara dalam satuan persen mulai dari Indonesia, Korea Selatan, India, Brasil dan Meksiko. Persentase perkembangan tertinggi dari tahun 2008 sampai dengan 2018 adalah negara Meksiko, yang kemudian disusul oleh Brasil, India, Korea Selatan dan Indonesia. Fluktuasi jumlah uang beredar di lima negara menunjukkan data perkembangan persentase yang beragam. Pada tahun 2015, Indonesia menunjukkan angka $8,99 \%$ dimana tahun sebelumnya adalah sebesar $11,88 \%$. Korea Selatan menunjukkan angka perkembangan jumlah uang beredar sebesar $8,19 \%$ dimana tahun sebelumnya sebesar $8,14 \%$ dan negara Brasil menunjukkan angka sebesar $10,62 \%$ dimana tahun sebelumnya sebesar $10,58 \%$ dan negara meksiko mengalami peningkatan angka persentase jumlah uang beredar yaitu sebesar $12,31 \%$ dimana tahun sebelumnya yakni sebesar $12,19 \%$. Hal ini dikarenakan ketidakstabilan harga minyak dunia dan defisit neraca pembayaran yang terjadi di empat dari lima negara tersebut pada tahun yang bersagkutan.

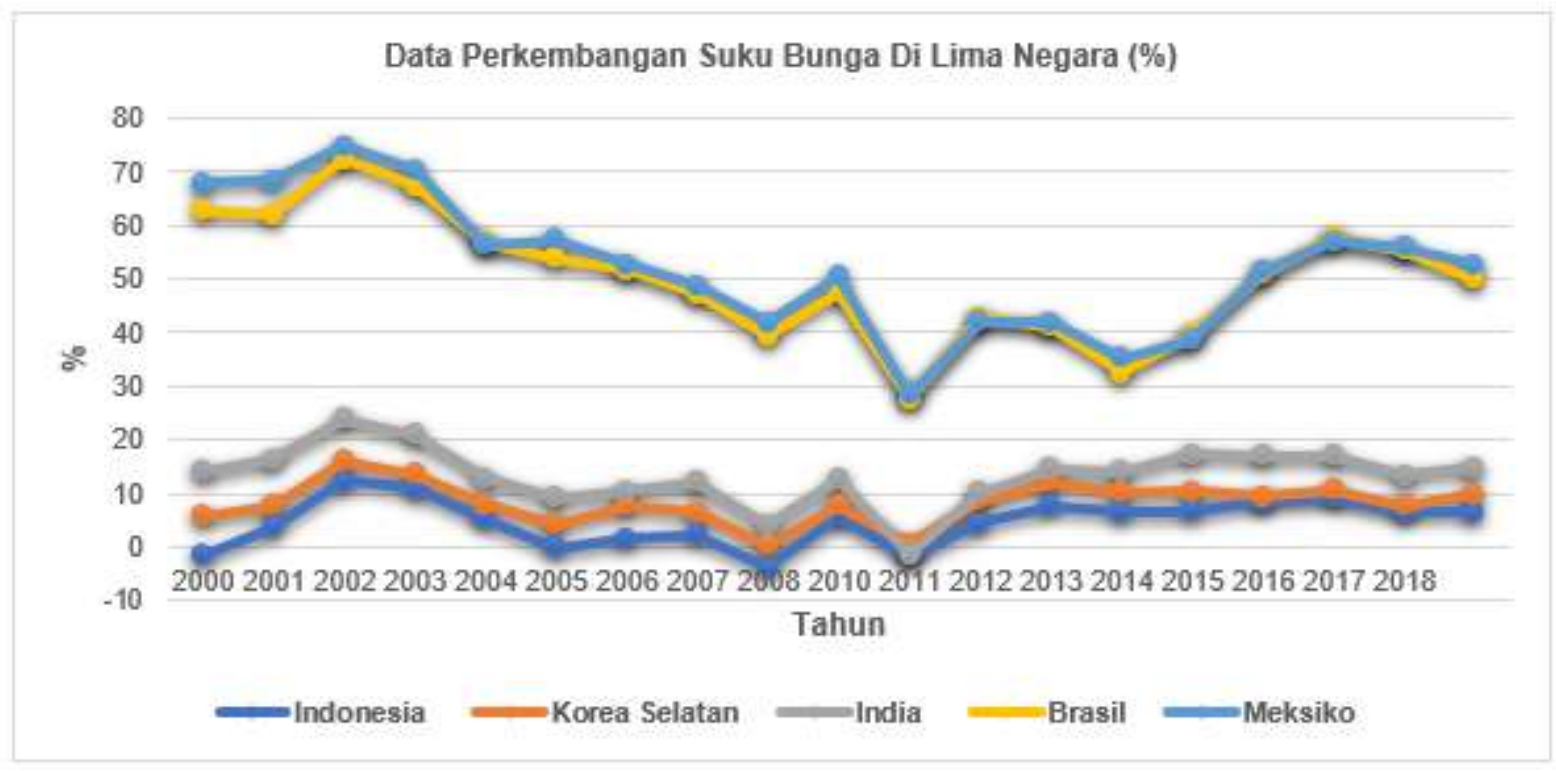

\section{Sumber: World Bank}

Gambar 4. Perkembangan Suku Bunga Di Lima Negara (2000-2018) 
Tingkat suku bunga domestik yang rendah mendorong penggunaan uang dari kredit/pinjaman bank oleh masyarakat dalam kegiatan usaha dan meningkatkan produktivitas kegiatan ekonomi. Konsumen menggunakan uang untuk dibelanjakan ke pasar daripada hanya sekedar menyimpan uangnya di bank dalam bentuk deposito (Muchlas, Z; Alamsyah, 2015). Dan begitu pula sebaliknya apabila tingkat suku bunga domestik yang tinggi cenderung mendorong masyarakat untuk mengambil keputusan menyimpang uangnya di bank. Berdasarkan Gambar, dapat diketahui bahwa adanya kenaikan tingkat suku bunga yang dialami ke lima negara mengalami fluktuasi setiap tahunnya. Pada tahun 2015 negara Indonesia mengalami kenaikan suku bunga sebesar 8,35\% dimana tahun sebelumnya sebesar $6,79 \%$. India juga mengalami hal yang sama menunjukkan angka sebesar 7,55\% dimana tahun sebelumnya sebesar 6,69\% diikuti negara Brasil dan Meksiko dimana negara Brasil tingkat suku bunga adalah naik sebesar 33,83\% yang tahun sebelumnya sebesar $22,40 \%$ sedangkan Meksiko meningkat yaitu sebesar 0,61\% dimana tahun sebelumnya sebesar $-0,83 \%$. Sedangkan negara Korea Selatan, tingkat suku bunga adalah stabil. Kenaikan tingkat suku bunga di negara-negara tersebut pada tahun 2015 oleh karena krisis ekonomi global, inflasi yang tinggi juga ketidakstabilan tingkat suku bunga AS.

Tabel 2. Hasil Estimasi Panel-Two Stage Least Square

\begin{tabular}{|c|c|c|c|c|}
\hline Persamaan & Variabel & Koefisien & t-Statistic & Prob. \\
\hline \multirow[t]{4}{*}{ NPI } & $\mathrm{C}$ & 3.587370 & 1.809373 & 0.0747 \\
\hline & NX & 4.787711 & 5.856828 & $0.0000^{*}$ \\
\hline & INF & 0.019256 & 0.225991 & 0.8219 \\
\hline & KURS & -0.001581 & -2.118906 & $0.0377^{*}$ \\
\hline \multicolumn{2}{|c|}{ R-squared } & 0.789940 & F-statistic & 11.44379 \\
\hline \multicolumn{2}{|c|}{ Adjusted R-squared } & 0.713831 & Prob. & $0.000000^{*}$ \\
\hline \multirow[t]{4}{*}{ KURS } & C & 1954.464 & 7.169144 & 0.0000 \\
\hline & JUB & -5.775947 & -0.522975 & 0.6027 \\
\hline & SB & 39.13868 & 1.932344 & $0.0574^{*}$ \\
\hline & $\mathrm{NPI}$ & -134.0804 & -2.243132 & $0.0281^{*}$ \\
\hline \multicolumn{2}{|c|}{ R-squared } & 0.975997 & F-statistic & 96.52250 \\
\hline \multicolumn{2}{|c|}{ Adjusted R-squared } & 0.967300 & Prob. & $0.000000^{*}$ \\
\hline
\end{tabular}

Sumber: data diolah (2020); EViews v.10; * sig. pada $\alpha=10 \%$

Hasil uji identifikasi menunjukkan over identified pada kedua persamaan sehingga digunakan metode Two Stage Least Square (TSLS) pada persamaan simultan dalam penelitian ini. Persamaan simultan mencirikan bahwa antar variabel tidak hanya memiliki hubungan yang satu arah akan tetapi antar variabel tersebut adalah saling mempengaruhi (Widarjono, 2014). Berdasarkan estimasi Panel-Two Stage Least Square diperoleh hasil model persamaan simultan seperti berikut ini:

$$
\begin{aligned}
& \mathrm{NPI}_{\mathrm{t}}=3,587370+4,787711 \mathrm{NX}+0,019256 \mathrm{INF}-0,001581 \mathrm{KURS}+\mathrm{e}_{1} \\
& \mathrm{KURS}_{\mathrm{t}}=1954,464-5,775947 \mathrm{JUB}+39,13868 \mathrm{SB}-134,0804 \mathrm{NPI}+\mathrm{e}_{2}
\end{aligned}
$$

Dari hasil estimasi, persamaan (3) menunjukkan bahwa apabila net ekspor, inflasi dan kurs bernilai 0 (nol) maka neraca pembayaran di lima negara naik secara signifikan sebesar 3,59 persen. Koefisien determinasi (R-squared) pada persamaan (3) menunjukkan angka 0,789940 artinya bahwa sebesar 78,99 persen kontribusi pengaruh variabel net ekspor, inflasi dan kurs secara simultan terhadap variabel neraca pembayaran di lima negara. Dan sisanya sebesar 21,01 persen neraca pembayaran di lima negara dipengaruhi oleh variabelvariabel lain di luar model penelitian. Net ekspor, inflasi dan kurs secara simultan berpengaruh positif dan signifikan terhadap neraca pembayaran di lima negara yang ditandai dengan nilai F-statistic $>$ F-tabel yakni 11,44 $>2,32$ dan nilai Prob. 0,000000< $\alpha=$ 
0,10. Artinya bahwa apabila net ekspor, inflasi dan kurs secara bersama-sama naik, maka neraca pembayaran di lima negara tersebut pun akan mengalami peningkatan secara signifikan sebesar 11,44 persen dalam kurun waktu penelitian cateris paribus.

Net ekspor berpengaruh positif dan signifikan terhadap neraca pembayaran di lima negara yang ditandai dengan nilai t-statistic > t-tabel yakni 5,856828 >1,66216 dan nilai Prob. $0,0000<\alpha=0,10$. Artinya bahwa apabila net ekspor di lima negara naik sebesar US\$ 1 milyar maka akan meningkatkan neraca pembayaran di lima negara tersebut secara signifikan sebesar 4,79 persen cateris paribus. Sehingga berdasarkan hasil penelitian bahwa net ekspor berpengaruh secara positif dan signifikan terhadap neraca pembayaran, ini sesuai dengan hasil penelitian terdahulu yang menyatakan bahwa net ekspor yang merupakan nilai pengurangan ekspor dan impor atau disebut juga neraca dagang mempunyai hubungan korelasi yang sangat kuat terhadap neraca pembayaran (Wiryanti, 2015). Kegiatan ekspor impor yang meningkat dapat mendorong surplus neraca pembayaran di Indonesia, Korea Selatan, India, Brasil dan Meksiko.

Inflasi berpengaruh positif dan tidak signifikan berpengaruh terhadap neraca pembayaran di lima negara yang ditandai dengan nilai t-statistic < t-tabel yakni sebesar 0,225991 < 1,66216 dan nilai Prob. 0,8219 $>\alpha=0,10$. Artinya bahwa apabila inflasi di lima negara naik sebesar $1 \%$ maka secara positif namun tidak signifikan meningkatkan neraca pembayaran di lima negara tersebut sebesar 0,02 persen cateris paribus.

Kurs berpengaruh negatif dan signifikan berpengaruh terhadap neraca pembayaran di lima negara yang ditandai dengan nilai t-statistc $>t$ - tabel yakni sebesar 2,115906 $>1,66216$ dan nilai Prob. $0,0377<\alpha=0,10$. Artinya bahwa apabila kurs di lima negara terapresiasi sebesar 1 LCU maka secara signifikan menurunkan neraca pembayaran di lima negara tersebut sebesar 0,00 persen cateris paribus. Sehingga berdasarkan hasil penelitian bahwa kurs berpengaruh negatif terhadap neraca pembayaran, ini sesuai penelitian terdahulu yang menyatakan bahwa dalam jangka pendek dan jangka panjang kurs berpengaruh negatif terhadap neraca pembayaran (Destiandy, Riza A; Amaliah, Ima; Rocaeti, 2016). Kurs mata uang di lima negara yang terdepresiasi akan mendorong surplus neraca pembayaran pada lima negara tersebut dalam penelitian, dan begitu pula sebaliknya.

Dari hasil estimasi, persamaan (4) menunjukkan bahwa apabila jumlah uang beredar, suku bunga dan neraca pembayaran maka kurs di lima negara terapresiasi secara signifikan sebesar 1954,464 LCU. Koefisien determinasi (R-squared) pada persamaan (4) menunjukkan angka 0,975997 artinya bahwa sebesar 97,60 persen kontribusi pengaruh variabel jumlah uang beredar, suku bunga dan neraca pembayaran secara simultan terhadap variabel kurs di lima negara. Dan sisanya sebesar 2,40 persen kurs di lima negara dipengaruhi oleh variabel-variabel lain di luar model penelitian. Jumlah uang beredar, suku bunga dan neraca pembayaran secara simultan berpengaruh positif dan signifikan terhadap kurs di lima negara yang ditandai dengan nilai F-statistic > F-tabel yakni 96,52 > 2,32 dan nilai Prob. 0,000000 $<\alpha=0,10$. Artinya bahwa apabila jumlah uang beredar, suku bunga dan neraca pembayaran secara bersama-sama naik, maka kurs mata uang di lima negara tersebut pun akan mengalami peningkatan secara signifikan sebesar 96,52 LCU dalam kurun waktu penelitian cateris paribus.

Jumlah uang beredar di lima negara berpengaruh negatif namun tidak signifikan terhadap kurs di lima negara tersebut yang ditandai dengan nilai t-statistic < t-tabel yakni sebesar 0,522975 <1,66216 dan nilai Prob. 0,6027 $>\alpha=0,10$. Artinya bahwa apabila jumlah uang beredar naik sebesar 1 persen maka secara negatif dan tidak signifikan mempengaruhi kurs di lima negara sebesar 5,775947 LCU cateris paribus.

Suku bunga berpengaruh positif dan signifikan terhadap kurs di lima negara yang ditandai dengan nilai t-tatistic $>$ t-tabel yakni sebesar 1,932344 >1,66216 dan nilai Prob. 0,0574< $\alpha$ $=0,10$. Artinya bahwa apabila suku bunga naik di lima negara sebesar 1 persen maka secara positif dan signifikan mempengaruhi apresiasi kurs di lima negara tersebut sebesar 39,14 persen cateris paribus. Sehingga hasil penelitian ini sesuai dengan penelitian terdahulu yang menyatakan tingkat suku bunga berpengaruh positif terhadap kurs suatu negara (Utomo; Fauziyah, 2017). Tingkat suku bunga domestik yang naik mendorong 
penguatan nilai mata uang di negara tersebut karena mendorong investor untuk menanamkan modal sehingga aliran modal masuk ini yang mendukung peningkatan nilai mata uang di negara yang bersangkutan.

Neraca pembayaran berpengaruh negatif dan signifikan terhadap kurs di lima negara yang ditandai dengan nilai t-statistic $>$ t-tabel yakni sebesar 2,243132 > 1,66216 dan nilai Prob. $0.0281<\alpha=0,10$. Artinya bahwa apabila neraca pembayaran di lima negara naik sebesar 1 persen maka secara signifikan kurs di lima negara tersebut terdepresiasi sebesar 134,0804 LCU cateris paribus. Sehingga berdasarkan hasil penelitian bahwa neraca pembayaran berpengaruh negatif dan signifikan terhadap kurs, ini sesuai dengan hasil penelitian terdahulu yang menyatakan neraca pembayaran memberi pengaruh negatif terhadap kurs suatu negara (Muchlas, Z; Alamsyah, 2015). Ini dijelaskan apabila pada tahapan neraca pembayaran yang defisit berarti pemerintah mendorong peningkatan impor. Impor yang meningkat mencerminkan peningkatan terhadap nilai valuta asing netto dengan demikian akan mengakibatkan apresiasi mata uang domestik pada lima negara yang bersangkutan dalam penelitian terhadap mata uang asing, (Saputra, 2015) begitupun sebaliknya apresiasi kurs suatu negara mempengaruhi impor.

Dengan demikian, semakin meningkat angka net ekspor di lima negara maka secara signifikan meningkatkan surplus pada neraca pembayaran di Indonesia, Korea Selatan, India, Brasil dan Meksiko selama kurun waktu penelitian. Inflasi yang meningkat di lima negara secara tidak signifikan meningkatkan surplus neraca pembayaran di Indonesia, Korea Selatan, India, Brasil dan Meksiko selama kurun waktu penelitian. Dan apabila terjadi penguatan kurs mata uang di lima negara maka secara signifikan mengakibatkan defisit neraca pembayaran di Indonesia, Korea Selatan, India, Brasil dan Meksiko selama kurun waktu penelitian. Jumlah uang beredar yang meningkat di lima negara secara tidak signifikan mengakibatkan depresiasi kurs mata uang di Indonesia, Korea Selatan, India, Brasil dan Meksiko selama kurun waktu penelitian. Apabila tingkat suku bunga meningkat di lima negara secara signifikan mengakibatkan terjadinya penguatan kurs mata uang di Indonesia, Korea Selatan, India, Brasil dan Meksiko dalam kurun waktu penelitian. Dan apabila terjadi surplus neraca pembayaran di lima negara secara signifikan akan terjadi pelemahan atau depresiasi mata uang di Indonesia, Korea Selatan, India, Brasil dan Meksiko dalam kurun waktu penelitian, cateris paribus.

\section{KESIMPULAN}

Net ekspor secara positif dan signifikan mempengaruhi pergerakan perkembangan neraca pembayaran di Indonesia, Korea Selatan, India, Brasil dan Meksiko. Inflasi secara positif namun tidak signifikan mempengaruhi perkembangan neraca pembayaran di Indonesia, Korea Selatan, India, Brasil dan Meksiko.

Jumlah uang beredar secara negatif dan tidak signifikan mempengaruhi kurs mata uang negara Indonesia, Korea Selatan, India, Brasil dan Meksiko. Tingkat suku bunga secara positif dan signifikan mempengaruhi kurs mata uang negara Indonesia, Korea Selatan, India, Brasil dan Meksiko.

Efek simultanitas variabel ekonomi moneter terhadap neraca pembayaran dapat dijelaskan melalui variabel kurs dan neraca pembayaran di lima negara yakni Indonesia, Korea Selatan, India, Brasil dan Meksiko adalah saling mempengaruhi. Ditunjukkan bahwa kurs mata uang negara Indonesia, Korea Selatan, India, Brasil dan Meksiko adalah negatif secara signifikan mempengaruhi neraca pembayaran di negara Indonesia, Korea Selatan, India, Brasil dan Meksiko. Pun neraca pembayaran di Indonesia, Korea Selatan, India, Brasil dan Meksiko secara negatif dan signifikan mempengaruhi kurs mata uang negara Indonesia, Korea Selatan, India, Brasil dan Meksiko.

Implikasi penelitian ini diharapkan kepada pemerintah terutama Bank Indonesia dapat menjaga kestabilan rupiah domestik agar penguatan nilai mata uang lebih tercapai dan kepada Kementerian Perdagangan dapat menuju target surplus neraca pembayaran sehingga dapat mempengaruhi kestabilan kurs domestik pula menuju angka pertumbuhan 
ekonomi yang lebih tinggi. Penelitian ini masih butuh pembaharuan, diharapkan kepada peneliti selanjutnya untuk menambahkan variabel dan jumlah negara sehingga memberikan interpretasi hasil sebagai referensi bagi peneliti yang membutuhkan di kemudian hari.

\section{DAFTAR PUSTAKA}

Ajija, Shochrul Rohmatul, D. (2011). Cara Cerdas Menguasai Eviews. In Jakarta (1st ed.). Jakarta: Salemba Empat.

Astuti, IP; Oktavilia, S. R. A. (2015). Peranan Neraca Pembayaran Internasional Dalam Perekonomian Indonesia. Jejak, 8(2), 178-188. Retrieved from https://www.researchgate.net/publication/307850021_Peranan_Neraca_Pembayaran_I nternasional_Dalam_Perekonomian_Indonesia

BI. (2020). Neraca Pembayaran. Retrieved from Bank Indonesia website: https://www.bi.go.id/id/publikasi/neraca-pembayaran/Default.aspx

Destiandy, Riza A; Amaliah, Ima; Rocaeti, A. (2016). Pengaruh Nilai Tukar Rupiah Per Dollar AS terhadap Neraca Pembayaran di Indonesia Periode 2008-2014. Prosiding IImu Ekonomi, 2(1), 67-72. Retrieved from https://docplayer.info/32540828-Pengaruh-nilaitukar-rupiah-per-dollar-as-terhadap-neraca-pembayaran-di-indonesia-periode.html

Dewi, A. C. (2018). Analisis Faktor Yang Mempengaruhi Kurs Rupiah Di Indonesia (No. 1). Retrieved from http://eprints.ums.ac.id/65553/1/NASKAH PUBLIKASI.pdf

Julian, D. (2016). Analisis Pendekatan Keynesian Terhadap Neraca Pembayaran Di Indonesia Periode 2004:Q1-2015:Q3 (Universitas Lampung). Retrieved from http://digilib.unila.ac.id/21319/3/SKRIPSI TANPA BAB PEMBAHASAN.pdf

Leonufna, L; Kumaat, R; Mandeij, D. (2016). Analisis Pengaruh Neraca Pembayaran Internasional Terhadap Tingkat Kurs Rupiah/Dollar As Melalui Cadangan Devisa Dalam Sistem Kurs Mengambang Bebas Di Indonesia Periode 1998.1 Sampai 2014.4. Efisiensi, 16(2), 315-324. Retrieved from https://ejournal.unsrat.ac.id/index.php/jbie/article/view/12405/11978

Muchlas, Z; Alamsyah, A. (2015). Faktor-Faktor Yang Mempengaruhi Kurs Rupiah Terhadap Dolar Amerika Pasca Krisis (2000-2010). JIBEKA, 9(1), 76-86. Retrieved from Inflation, Interest rate, the Money Supply, GDP, BOP, Exchange rate movements IDR/USD

Oktavia, A. L. (2016). Analisis Faktor-faktor yang Mempengaruhi Kurs dan Jumlah Uang Beredar di Indonesia. JUSIE, 1(1), 2-11. Retrieved from https://www.mendeley.com/catalogue/6639b72e-5a3c-3928-beee-8e2db1687816/

Salvatore, D. (2014). Ekonomi Internasional Edisi 9 Buku 2 (9th ed.). Jakarta: Salemba Empat.

Saputra, F. D. (2015). Analisis impor Indonesia dari Cina. Perdagangan, Industri Dan Moneter, 3(1), 16-21. Retrieved from https://onlinejournal.unja.ac.id/pim/article/view/3989/2905

Sunardi, N., \& Ula, L. N. R. (2017). Pengaruh BI Rate, Inflasi Dan Kurs Terhadap Indeks Harga Saham Gabungan (IHSG). Jurnal Sekuritas: Saham, Ekonomi, Keuangan dan Investasi, 1(2), 27-41. 
Sunardi, N. (2019). Mekanisme Good Corporate Governance Terhadap Nilai Perusahaan Dengan Leverage Sebagai Variabel Intervening Pada Perusahaan Manufaktur Yang Terdaftar Di Bursa Efek Indonesia Tahun 2012-2018. JIMF (Jurnal IImiah Manajemen Forkamma), 2(3).

Sunardi, N. (2019). Profitabilitas, Likuiditas, Dan Multiplier Equity Pengaruhnya Terhadap Harga Serta Return Saham Pada Industri Manufaktur Tahun 2012-2017. INOVASI, 6(1), 58-73.

Syah, R. R. (2017). Analisis Faktor-Faktor Yang Mempengaruhi Jumlah Uang Beredar Di Indonesia (Universitas Pasundan). Retrieved from http://repository.unpas.ac.id/30481/3/03 ABSTRAK \%28SA\%29 final FIX.pdf

Utomo; Fauziyah, E. (2017). Faktor - Faktor Determinan Kurs Rupiah Terhadap Dollar Amerika. Media Trend, 12(1), 12-23. Retrieved from https://journal.trunojoyo.ac.id/mediatrend/article/view/2153/2191

Widarjono, A. (2014). Ekonometrika Pengantar dan Aplikasinya Disertai Panduan EViews (1st ed.). Yogyakarta: UPP STIM YKPN Yogyakarta.

Wiryanti, T. (2015). Korelasi Ekspor Dan Impor Terhadap Neraca Perdagangan Dan Neraca Pembayaran Di Indonesia Tahun 2003-2013. KREATIF, 2(2), 111-128. Retrieved from http://openjournal.unpam.ac.id/index.php/kreatif/article/view/462/382 